Chapman University

Chapman University Digital Commons

Food Science Faculty Articles and Research

Food Science

$4-2015$

\title{
Identification of Meat Species in Pet Foods Using a Real-time Polymerase Chain Reaction (PCR) Assay
}

Tara A. Okuma

Chapman University

Rosalee S. Hellberg

Chapman University, hellberg@chapman.edu

Follow this and additional works at: http://digitalcommons.chapman.edu/food_science_articles

Part of the Food Biotechnology Commons, Food Processing Commons, Meat Science Commons, and the Other Food Science Commons

\section{Recommended Citation}

Okuma TA, Hellberg RS. 2015. Identification of meat species in pet foods using a real-time polymerase chain reaction (PCR) assay. Food Control 50: 9-17.

doi: 10.1016/j.foodcont.2014.08.017

This Article is brought to you for free and open access by the Food Science at Chapman University Digital Commons. It has been accepted for inclusion in Food Science Faculty Articles and Research by an authorized administrator of Chapman University Digital Commons. For more information, please contact laughtin@chapman.edu. 


\title{
Identification of Meat Species in Pet Foods Using a Real-time Polymerase Chain Reaction (PCR) Assay
}

\author{
Comments \\ NOTICE: this is the author's version of a work that was accepted for publication in Food Control. Changes \\ resulting from the publishing process, such as peer review, editing, corrections, structural formatting, and \\ other quality control mechanisms may not be reflected in this document. Changes may have been made to this \\ work since it was submitted for publication. A definitive version was subsequently published in Food Control, \\ volume 50, in 2015. DOI: 10.1016/j.foodcont.2014.08.017 \\ The Creative Commons license below applies only to this version of the article.
}

\section{Creative Commons License}

\section{(c) 1 (1) 90}

This work is licensed under a Creative Commons Attribution-Noncommercial-No Derivative Works 4.0 License.

\section{Copyright}

Elsevier 
4 Authors: Tara A. Okuma ${ }^{\mathrm{a}}$, Rosalee S. Hellberg ${ }^{\mathrm{b}^{*}}$

$6 \quad{ }^{a}$ Chapman University, Schmid College of Science and Technology, Biochemistry and Molecular

7 Biology, One University Drive, Orange, CA USA 92866

$8 \quad{ }^{b}$ Chapman University, Schmid College of Science and Technology, Food Science and Nutrition,

9 One University Drive, Orange, CA USA 92866

10

11 *Corresponding author: Rosalee S. Hellberg, e-mail: hellberg@chapman.edu, Ph: +1-714-628-

$12 \quad 2811$

13

14 


\section{Abstract}

16 Product mislabeling, adulteration, and substitution are increasing concerns in highly processed

17 foods, including pet foods. Although regulations exist for pet foods, there is currently a lack of

18 information on the prevalence of pet food mislabeling. The objective of this study was to

19 perform a market survey of pet foods and pet treats marketed for domestic canines and felines to

20 identify meat species present as well as any instances of mislabeling. Fifty-two commercial

21 products were collected from online and retail sources. DNA was extracted from each product in

22 duplicate and tested for the presence of eight meat species (bovine, caprine, ovine, chicken,

23 goose, turkey, porcine, and equine) using real-time polymerase chain reaction (PCR) with SYBR

24 Green and species-specific primers. Of the 52 tested products, 31 were labeled correctly, 20 were

25 potentially mislabeled, and 1 contained a non-specific meat ingredient that could not be verified.

26 Chicken was the most common meat species found in the pet food products $(n=51)$, and none of

27 the products tested positive for horsemeat. In three cases of potential mislabeling, one or two

28 meat species were substituted for other meat species, but major trends were not observed. While

29 these results suggest the occurrence of pet food mislabeling, further studies are needed to

30 determine the extent of mislabeling and identify points in the production chain where

31 mislabeling occurs.

\section{Keywords}

33 Pet foods, real-time PCR, meat species identification, mislabeling, adulteration, species

34 substitution 


\section{Introduction}

The pet food industry, including pet foods and other pet products and services, is a growing market in the United States. Over the past five years, U.S. pet industry expenditures

41 have increased by approximately $\$ 10$ billion, with close to $\$ 21$ billion spent on pet food alone in 2012 (APPA, 2013). The U.S. Bureau of Labor Statistics (BLS) reports that nearly 75\% of U.S.

43 households own pets, totaling about 218 million pets, not including fish (Henderson, 2013). On

44 average, each U.S. household spends more than $\$ 500$ on pets annually, equating to about $1 \%$ of household expenditures.

The foods developed for pets are regulated by both federal and state entities. The U.S. Food and Drug Administration (FDA) Center for Veterinary Medicine (CVM) regulates animal feed and pet foods under the Federal Food, Drug, and Cosmetic Act (FFDCA). For product labeling standards, the FDA regulates product identification, net quantity, manufacturer's contact information, and the proper listing of ingredients (FDA, 2010). The Association of American Feed Control Officials (AAFCO), composed of state, federal, and international regulatory officials, is not a regulatory entity but has established a model of pet food regulations and guidelines that has been adopted by the FDA and many state regulatory offices. While it does not product imports and exports.

Although regulations exist for pet foods, increases in international trade and globalization of the food supply have amplified the potential for food fraud to occur. Food fraud is defined as "the deliberate and intentional substitution, addition, tampering, or misrepresentation of food, 60 food ingredients, or food packaging; or false or misleading statements made about a product, for 
61 economic gain," and it also greatly affects food safety and public health (Moore, Spink, \& Lipp,

62 2012; Spink \& Moyer, 2011, 2013). There are numerous possibilities for mislabeling and

63 misidentification of meat species throughout the production chain, including at the abattoir, at

64 meat and meat by-product processing plants, and at the food product manufacturing plant

65 (Premanandh, 2013). The potential issues concerning meat and meat product authenticity include

66 species misidentification, undeclared animal parts and ingredients, undeclared additives, and

67 product origin (Montowska \& Pospiech, 2011). Few studies have been published surveying meat

68 species identification and mislabeling in processed foods for human consumption, let alone pet

69 foods, suggesting a need for further research in this area. A South African study performed on

70 species substitution and mislabeling of meat products reported that pork was the most commonly

71 substituted meat, which poses a risk for Muslim and Jewish dietary restrictions (Cawthorn,

72 Steinman, \& Hoffman, 2013). In the same study, unapproved meat for human consumption-

73 donkey, goat, and water buffalo — was detected in several of the tested processed and packaged

74 meat products. Meat substitutions due to undeclared meat species were also detected in previous

75 studies testing raw and cooked processed meat products for human consumption from the U.S.,

76 Turkey, Mexico, and Istanbul (Ayaz, Ayaz, \& Erol, 2006; Flores-Munguia, Bermudez-Almada,

77 \& Vazquez-Moreno, 2000; Hsieh, Woodward, \& Ho, 1995; Ozpinar, Tezmen, Gokce, \& Tekiner, 78 2013).

Processed meat products present a challenge in terms of food fraud detection, as meat

80 species in these foods may be impossible to distinguish visually and may consist of a mixture of

81 multiple species. For example, undeclared horsemeat was found in several Mexican hamburger

82 and sausage products, as well as in raw meat samples from Turkey, which declared the products

83 as beef (Ayaz et al., 2006; Flores-Munguia et al., 2000). With the recent discovery of horsemeat 
84 in ground meat products sold for human consumption in several European countries, the

85 presence of horsemeat in U.S. consumer food and pet food products is also a concern (O'Mahony,

86

87 2013; Stanciu, Stanciuc, Dumitrascu, Ion, \& Nistor, 2013). Considering the vast network in existence of global imports and exports, it is feasible that food fraud in one part of the world could spread elsewhere. One area where this possibility exists is in the cattle trade, for which the U.S. is the only major exporter that does not have a mandatory cattle traceability system or standards in place (Schroeder \& Tonsor, 2012). Even though the USDA has implemented standards for animal disease traceability, the purpose of these standards is to only regulate and trace livestock moving interstate when diseased animals are found (USDA, 2013). The lack of a comprehensive cattle traceability system in the U.S. may increase the potential for meat species substitution and mislabeling (Shackell, 2008).

In addition to pet food mislabeling and food fraud, pet food safety is another area of concern, especially with commercialized pet foods that are specifically formulated to address immunological adverse food reactions (AFR). AFR are food allergies that may occur in both dogs and cats regardless of breed, sex, or age, causing chronic dermatological disorders and gastrointestinal diseases (Verlinden, Hesta, Millet, \& Janssens, 2006; Vogelnest \& Cheng, 2013). Some common food allergens in dogs and cats include meat proteins, such as beef and chicken (Raditic, Remillard, \& Tater, 2011; Vogelnest \& Cheng, 2013). AFR is typically diagnosed by an elimination diet, which limits the number of proteins in the diet and helps to identify the cause of the immunological response(s); the main treatment for AFR is to eliminate the cause of the reaction (Verlinden et al., 2006). Homemade diets are usually recommended, but commercial novel protein diets (NPD) and hydrolyzed protein diets (HPD) are also available on the market and usually contain one protein source; therefore, it is important that these pet food products are 
107 correctly labeled (Ricci et al., 2013; Verlinden et al., 2006). However, studies have shown that 108 some NPD and HPD are mislabeled. In one study, undeclared mammalian and avian DNA and 109 bone fragments were found in 10 of the 12 tested dry NPD and HPD products for dogs (Ricci et 110 al., 2013). Another study found undeclared beef proteins in a dry dog food product listing 111 venison as the only meat ingredient (Raditic et al., 2011). It is highly important to ensure that 112 these pet food products on the market are safe and correctly labeled because incorrectly labeled 113 products may cause elimination diets to fail and result in undiagnosed AFR in dogs and cats 114 suffering from mild to severe chronic immunological response(s).

115 Meat species are commonly identified in foods using either DNA or protein analyses 116 (Ballin, Vogensen, \& Karlsson, 2009). Protein analyses, such as immunoassays, identify species 117 through specific antigen-antibody interactions; however, they are limited to characterizing 118 processed animal proteins (PAP) (Ballin et al., 2009). These proteins are challenging to analyze 119 in certain processed foods because some proteins are specific to certain tissues and may not be 120 found in a given product. In these circumstances, DNA-based methods, such as the polymerase 121 chain reaction (PCR), are advantageous in that DNA is found in practically all tissues and is 122 stable at higher temperatures (Ballin et al., 2009). The specific animal tissues contained in 123 processed foods are sometimes unknown and are present in mixtures; therefore, DNA analyses 124 are ideal in identifying meat species in highly processed foods (Ballin et al., 2009). Among DNA 125 targets, mitochondrial DNA (mtDNA) is desirable in these food types because it is present at a 126 higher copy number than chromosomal DNA and is therefore more likely to be detected during 127 PCR (Ballin et al., 2009). One method that shows considerable promise for identification of meat 128 species in heavily processed foods and feeds is real-time PCR (Yancy et al., 2009). This method 
129 is highly sensitive, rapid, and can be used to identify species in mixed products containing meat

130 from multiple species.

131 The objective of this study was to perform a market survey of commercial canine and

132 feline pet foods in order to identify the types of meat species present in these products as well as

133 any instances of pet food mislabeling. This objective was accomplished using a real-time PCR

134 assay targeting regions of mtDNA in eight different meat species.

135 2. Materials and Methods

$136 \quad 2.1$ Sample collection and preparation

137 A total of 52 commercial canine and feline pet food products representing a variety of

138 meat species and processing methods were collected from retail stores in Orange County,

139 California, and online stores in July and August 2013. Each pet food product was randomly

140 assigned a unique three-digit sample identification number. The product's brand name, flavor or

141 description, net weight, ingredient list, lot number, expiration date, place of origin, and purchase

142 place and date were recorded. The USDA sample preparation and extraction standard protocols

143 (Section 17.4) for the identification of animal species in meat and poultry products were used for

144 the pet food sample preparation, with a few modifications (USDA, 2005). Sterileware scoops

145 (Scienceware, Wayne, NJ) or flame-sterilized tweezers were used to aseptically remove $30.0 \mathrm{~g}$ of

146 dry food products or treats that were placed into 24 oz. Whirl-Pak ${ }^{\circledR}$ Stand-up bags (Nasco, Fort

147 Atkinson, WI) with $60.0 \mathrm{~mL}$ of sterile water. The products were incubated at room temperature

148 for $1 \mathrm{~h}$ and then processed in a Seward Stomacher ${ }^{\circledR} 400$ Circulator (Seward USA, Port Saint

149 Lucie, FL) at $230 \mathrm{rpm}$ for $60 \mathrm{~s}$. The entire contents of wet food products were placed in $7 \mathrm{oz}$.

150 Whirl-Pak ${ }^{\circledR}$ Write-on bags (Nasco, Fort Atkinson, WI) and the bags were hand-mixed for $60 \mathrm{~s}$ to 
151 homogenize the samples. Two $\sim 10 \mathrm{mg}$ subsamples were collected from each product for DNA

152 extraction.

153

154

155

156

157

158

159

160

161

162

163

164

165

166

167

168

169

170

171

172

173

\subsection{DNA extraction and PCR preparation}

The DNA extraction portion of the Extract-N-Amp Tissue PCR Kit (\#XNAT2; Sigma-

Aldrich, St. Louis, MO) was used to extract the DNA in duplicate from each sample using half the volumes suggested by the manufacturer. Aliquots of $50.0 \mu \mathrm{L}$ of Extraction solution and 12.5 $\mu \mathrm{L}$ of Tissue Preparation solution were added to each tube containing a tissue subsample. A reagent blank was included with each DNA extraction as a negative control, and the samples were incubated at $55^{\circ} \mathrm{C}$ for $10 \mathrm{~min}$, and then at $95^{\circ} \mathrm{C}$ for an additional $3 \mathrm{~min}$. After both incubations, $50.0 \mu \mathrm{L}$ of Neutralization Solution B was added to each sample, and then the samples were centrifuged at $13,000 \mathrm{rpm}$ for $1 \mathrm{~min}$. The supernatant was carefully removed avoiding the lipid layer when present and without disturbing the pelleted debris. The extracted supernatant for each sample was then used as the extracted DNA template for real-time PCR. The quantity and quality of starting DNA was not determined, as DNA extracted with this method is a crude extract that could not be accurately measured with a spectrophotometer (Hellberg, Kawalek, Van, Shen, \& Williams-Hill, 2014).

\subsection{Real-Time PCR}

All real-time PCR amplification reactions were performed with the Rotor-Gene ${ }^{\circledR} \mathrm{Q}$ (RGQ) Real-Time PCR Cycler and software (Qiagen, Germantown, MD) and contained $12.5 \mu \mathrm{L}$ of $\mathrm{iQ}^{\mathrm{TM}} \mathrm{SYBR}^{\circledR}$ Green Supermix (2X) (Bio-Rad, Hercules, CA), $1.0 \mu \mathrm{L}$ of each oligonucleotide primer (forward and reverse), $8.5 \mu \mathrm{L}$ of sterile water, and $2.0 \mu \mathrm{L}$ of extracted DNA or control for a total reaction volume of $25.0 \mu \mathrm{L}$. All samples were tested for the presence of eight animal species (bovine, caprine, ovine, avian [chicken, goose, turkey], porcine, and equine) using 
174 species-specific primers described in previous studies (Kesmen, Sahin, \& Yetim, 2007; Yancy et 175 al., 2009). The final primer concentrations in each PCR reaction were $0.16 \mu \mathrm{M}$ for bovine, 0.25 $176 \mu \mathrm{M}$ for caprine and ovine, $0.2 \mu \mathrm{M}$ for avian, and $0.3 \mu \mathrm{M}$ for porcine and equine. Each PCR run 177 included the reagent blank from the DNA extraction, a no-template control, and a positive 178 control DNA. For the positive control, three 10-fold serial dilutions of DNA for each meat 179 species were made using Tris-EDTA buffer, pH 8.0 (E112-100ml; BioExpress, Kaysville, UT) 180 and were included in each PCR run. Thermocycling settings for bovine, caprine, ovine, and avian 181 were carried out as described in Yancy et al. (2009) with an initial incubation at $94^{\circ} \mathrm{C}$ for $2 \mathrm{~min}$ 182 and then 50 cycles of $94^{\circ} \mathrm{C}$ for $10 \mathrm{~s}, 58.9^{\circ} \mathrm{C}$ for $15 \mathrm{~s}$, and $72^{\circ} \mathrm{C}$ for $40 \mathrm{~s}$, with a single fluorescent 183 reading taken at the end of each cycle. The porcine and equine thermocycling conditions 184 included an initial incubation at $92^{\circ} \mathrm{C}$ for $2 \mathrm{~min}$ and then 35 cycles of $94^{\circ} \mathrm{C}$ for $50 \mathrm{~s}, 55^{\circ} \mathrm{C}$ for $50 \mathrm{~s}$ 185 (porcine) or $62^{\circ} \mathrm{C}$ for $50 \mathrm{~s}$ (equine), and $72^{\circ} \mathrm{C}$ for $60 \mathrm{~s}$ with a single fluorescent reading taken at 186 the end of each cycle and a final extension at $72^{\circ} \mathrm{C}$ for $5 \mathrm{~min}$. These conditions were taken from 187 the protocol originally described by Kesmen et al. (2007) for use with conventional PCR and 188 were only used after sensitivity testing showed the conventional and real-time PCR results to be 189 equivalent. A melt-curve analysis was completed at the end of each run for all meat species 190 tested to confirm the specificity of amplification. Both the threshold cycle (Ct) and melt-curve 191 values and threshold were set manually by comparison with positive controls. Results were 192 determined to be positive if at least one of the subsamples tested met the criteria of (1) having a $193 \mathrm{Ct}$ value for the meat species being tested and (2) having a melting temperature within $0.5^{\circ} \mathrm{C}$ of 194 the average positive control melting temperatures for that run. Results were qualitative and 195 reported in terms of presence or absence of a given species. In cases where a declared species 196 was found to be absent, additional testing was carried out to address the possibility of false 
197 negatives. Each of these samples was re-extracted and re-tested in duplicate. These samples were

198 also tested with positive control tissue spikes to account for possible inhibitors in the sample

199 matrix. Positive control tissue of the declared but not detected species was mixed with the pet

200 food sample at levels of $1 \%, 5 \%$, and $10 \%$. These spiked samples were then extracted using the

201 Extract-N-Amp Tissue PCR Kit and tested with real-time PCR, as described above. All spiking

202 tests were also carried out in duplicate.

2032.4 Statistical analyses

204 The rate of potentially mislabeled products was statistically compared across pet food 205 categories using IBM SPSS Statistics 21 (Armonk, NY). The rate of potentially mislabeled dog

206 food products was compared to the rate of potentially mislabeled cat food products using a

207 Pearson's chi-square test, with a pre-determined 2 -sided significance value of $p<0.05$. The rate

208 of potentially mislabeled dry foods, wet foods, and treats was compared using a Fisher's exact

209 test, with a predetermined 2-sided significance value of $p<0.017(0.05 / 3)$ based on the

210 Bonferroni correction for multiple tests.

\section{3. Results and Discussion}

2123.1 Meat species detected in pet foods

213 Meat species were identified and analyzed in all 52 commercial canine and feline pet

214 food products and treats collected for this study (Table 1). Some of the tested meat species in this 215 study were detected in many products while other meat species were detected in few or none of 216 the products. Of the eight meat species tested, chicken was the most commonly detected meat, 217 with 51 of the products testing positive (Fig. 1). The lower costs of chicken when compared to 218 beef or pork may explain, in part, why chicken was the most common meat ingredient detected 219 in the pet foods tested (NCC, 2012). Although the wholesale and retail prices of beef, pork, and 
chicken have increased every year since 1960, the 2012 wholesale and retail prices of chicken per pound were approximately $35 \%$ and $25 \%$ lower than wholesale and retail beef prices, respectively (NCC, 2012). The 2012 wholesale and retail prices for pork were between those for beef and chicken (NCC, 2012). Pork was the second most common meat species detected, with 224 positive identifications for 35 products, and beef, turkey, and lamb were detected in 34,32 , and 22526 products, respectively (Fig. 1). Goat and goose were detected sparingly in a few products 226 containing non-specific meat ingredients (e.g., animal fat, meat and bone meal, animal digest);

227 however, they were not specifically labeled as an ingredient in any of the tested pet food 228 products.

With the general lack of meat authentication testing and the recent food fraud and 230 horsemeat scandal in Europe, finding horsemeat in U.S. consumer food and pet food products is 231 a concern (O'Mahony, 2013; Premanandh, 2013). Due to the ability to detect low levels of 232 horsemeat in processed food products (Kesmen et al., 2007), each pet food product in this study 233 was tested for equine DNA; however, all of the tested pet food products were negative (Table 1). 234 This finding suggests that horsemeat was not incorporated nor used as a meat substitute in any of 235 the tested pet food products $(n=52)$, including in non-specific meat ingredients. More than half of the pet food products tested $(n=38)$ contained one or more non237 specific meat ingredient(s) (Table 1). Of those products, animal or poultry fat, meat by-products, 238 meat and bone meal (MBM), animal digest, and poultry by-product meal were the most common 239 non-specific meat ingredients listed on the product labels. The pet food industry has a large 240 demand for animal by-products, and hog (porcine) and steer (bovine) by-product values have 241 increased since 2000 (Marti, D. L., Johnson, R. J., \& Mathews, K. H., Jr., 2011). The value of 242 porcine by-products has increased $80.3 \%$ between 2000 and 2010 , and the value of bovine by- 
243 products has risen 34.8\% during the same time frame (Marti et al., 2011). Because of its use in

244 pet foods and in the medical industry, and with a rising demand on exports, animal by-product

245 use has increased over the years (Marti et al., 2011). Twenty-five products (14 dry foods and 11

246 pet treats) contained "animal fat" or "poultry fat" as an ingredient (Table 2), which is defined as

247 the fatty acid product from commercially rendered, extracted mammalian or poultry animal

248 tissue, respectively (AAFCO, 2013). Chicken was the most common species detected in these

249 products (Table 2), which may be expected considering the lower wholesale and retail prices for

250 chicken compared to those for beef and pork, as discussed above. Pork was the second most

251 common meat species detected in these products and the most common mammalian meat species

252 detected in products containing "animal fat" specifically. On the other hand, goose was the least

253 common meat species and detected in only one product that listed animal fat as its ingredient.

254 The ingredients "meat by-product" or "dried meat by-product," which are the clean and

255 non-rendered parts derived from mammals that are not considered meat or meat flesh (AAFCO,

256 2013), were included in 11 of the products tested (Table 2). Nine out of the eleven products

257 containing meat by-products as an ingredient were wet pet foods, and the other two were treats.

258 The most common detected species was pork, found in five of the 11 products. Five products (4

259 dry pet foods and 1 treat) listed MBM as an ingredient, which is considered the rendered meat

260 parts and bones from mammals (Table 2) (AAFCO, 2013). All of these products contained at

261 least two mammalian meat species, while one contained all four mammalian meat species

262 (bovine, caprine, ovine, and porcine). Additionally, "animal digest," defined as the clean and un-

263 decomposed animal tissues that have been obtained through chemical and/or enzymatic

264 hydrolysis, was included as an ingredient in five of the tested pet food products, all of which

265 were dry pet foods (Table 2) (AAFCO, 2013). Beef and chicken were detected in all of these 
products, whereas turkey and pork were detected in four of the products, lamb was detected in three of the products, and one product contained caprine meat. Poultry by-product meal consisting of the ground, rendered, and clean parts of poultry was listed as an ingredient in four of the tested dry pet food products (Table 2) (AAFCO, 2013). Both chicken and turkey were found in all products listing "poultry by-product meal" as an ingredient, while goose was not detected in any product containing poultry by-product meal.

\subsection{Pet food mislabeling}

Of the 52 products tested, 31 were found to be labeled correctly, meaning that all meat species included on the product label were detected in the sample, and undeclared meat species were not detected (Table 1). Twenty products were considered potentially mislabeled because they either (1) contained meat species that were not included on the product label and/or (2) did not contain meat species that were included on the product label. Labeling of one product (P011, wet cat food) listing "meat by-products" as an ingredient could not be verified because none of the five tested mammalian meat species were detected in the product. It is possible that the meat by-product ingredient contained other untested mammalian meat species. Another product, P016 (wet cat food), listed an animal species not tested in this study (i.e., venison) as an ingredient. Although the presence of venison could not be verified, the product was deemed potentially mislabeled based on the possible substitution of turkey and pork for beef and lamb (Table 1).

Of the 20 potentially mislabeled products, 13 were dog food and 7 were cat food; however, this difference was not statistically significant, according to a chi-square test (2-sided $p$-value $>0.05$ ). In comparing wet food, dry food, and treats, the rate of potentially mislabeled wet food products $(n=12 / 16)$ was found to be significantly higher than the rate of potentially mislabeled dry food products $(n=2 / 17)$, according to a Fisher's exact test with the Bonferroni 
correction ( $p$ value $<0.017$ ). However, there were no significant differences between the rate of potentially mislabeled treats $(n=6 / 18)$ and the rate of potentially mislabeled wet or dry foods.

Overall, these results indicate a higher frequency of mislabeling in wet foods compared to dry foods for the sample set analyzed in this study. Interestingly, half of the potentially mislabeled wet food products $(n=6)$ included one non-specific meat ingredient, whereas only one potentially mislabeled treat product listed a non-specific meat ingredient and none of the potentially mislabeled dry food products listed a non-specific meat ingredient.

Instances where meat species were included on the product's label but were not detected in the product occurred in seven of the 20 potentially mislabeled products, with bovine being the most common declared but undetected meat species (Table 1). These seven samples were subjected to spiking tests with positive control tissue to address the possibility of false negatives due to inhibition from the sample matrix. The results of the spiking tests with each product showed that the assay was able to detect tissue from pork, lamb and chicken at levels as low as $1 \%$ in all the sample matrices tested, and that turkey and beef could be detected at levels as low as $1-5 \%$, depending on the product. For example, among the four products with declared but undetected beef, one wet cat food product (P016) and one dog treat (P035) showed a detection limit for beef of 1\%, whereas two wet dog food products (P002 and P004) showed a detection limit for beef of $5 \%$. In three of the four products, beef was listed as either the first or second ingredient and also appeared later in the ingredient list, suggesting that detection should have been possible if the species was indeed present. Taken together, these results indicate that the seven products with declared but undetected species either (1) did not contain the declared meat species or (2) contained the declared meat species at levels below the detection limit for this assay. 
Meat species that were not included on the product label were detected in 16 of the 20

313 potentially mislabeled products, with pork being the most common undeclared meat species

314 detected (Table 1). For example, product P019 (dry dog food) was found to contain undeclared

315 ovine, turkey, and porcine ingredients in addition to the declared chicken and bovine ingredients.

316 In another instance with a cat treat product (P045), undeclared pork was detected in addition to

317 the declared chicken ingredients. Interestingly, in three cases, one to two meat species were

318 substituted for other meat species listed on the label. These included instances of undeclared

319 pork in place of beef in a wet dog food product (P002), undeclared turkey and pork in place of

320 beef and lamb in a wet cat food product (P016), and undeclared chicken in place of beef and

321 pork in a dog treat product (P035) (Table 1). Taken together, these results indicate a possible

322 trend for the substitution of lower-cost ingredients, such as poultry meats, for higher cost

323 ingredients, such as beef and lamb (Mundi, 2014; Raditic et al., 2011), although more research

324 would be needed to verify this trend.

For six products, meat species emphasized in the product name and/or description on the

326 front of the product packaging was not detected in the product. This occurred in four wet pet

327 foods and two pet treats, in which three of the products were for dogs and three for cats. The

328 declared but undetected meat species were beef, lamb, pork, and turkey, with beef being the most

329 common. Including a meat species in the product name when it is not actually detectable in the

330 product itself could be considered to be misleading according to the labeling requirements set

331 forth by the AAFCO model regulations for product naming (FDA, 2010). AAFCO's "flavor rule"

332 states that a sufficient amount of the meat or substance(s) that characterizes the meat flavor must

333 be used to avoid the product from being misleading (FDA, 2010). Product P002 (wet dog food)

334 listed "beef" in its product flavor description, and included deboned beef and beef broth as its 
335 first two ingredients, respectively; however, bovine DNA was not detected in this product (Table 336 1). Instead, pork was detected, indicating a possible meat substitution and a potentially

337 misleading product to consumers (Table 1). Another example was product P017 (wet cat food),

338 which listed "turkey" in its product flavor description and as its third ingredient, but turkey DNA

339 was not detected in the product. This product contained non-specific meat ingredients; however,

340 of the eight meat species tested, chicken and goat were the only meat species detected (Table 1).

341 Product P035 (dog treats) listed both "bacon and beef" in its product description and did not

342 include any non-specific meat ingredients; however, neither porcine nor bovine DNA were

343 detected in the product. Instead, chicken was the only meat species detected in product P035

344 (Table 1). These products could potentially be misleading to consumers and may pose a risk to

345 pets with AFR to certain meat proteins.

346 Similar to the findings of the current study, previous market studies have also found a

347 number of meat products to be mislabeled (Ayaz et al., 2006; Cawthorn et al., 2013; Flores-

348 Munguia et al., 2000; Hsieh et al., 1995; Ozpinar et al., 2013; Raditic et al., 2011), and pork has

349 been found to be a commonly undeclared but detected ingredient. For example, in the South

350 African study mentioned previously, $68 \%$ of processed and packaged meat products for human

351 consumption were found to contain undeclared plant and/or animal species, with pork being the

352 most common undeclared animal species (Cawthorn et al., 2013). In several processed meat

353 samples tested in Istanbul, undeclared horse, pork, and chicken meat were detected (Ozpinar et

354 al., 2013). It was also found that pork was substituted for beef, chicken was a substitute for pork-

355 based sausages, and over half (53.4\%) of samples were mislabeled (Ozpinar et al., 2013). In a

356 U.S. study conducted in Florida, meat substitution was detected in $16.6 \%$ of samples, with

357 incidences of mislabeling occurring more in cooked ground meat than in raw ground meat 
358 products (Hsieh et al., 1995). The study also found that sheep, pork, and poultry were the most 359 common undeclared meat species. Furthermore, in a study conducted in Mexico, some samples 360 of hamburger and sausage meat contained undeclared equine and porcine meat species (Flores361 Munguia et al., 2000). Many of the cooked or fermented sausages and ground meat products 362 collected in Turkey contained undeclared meat species, such as cooked "beef-only" samples 363 containing poultry meat and raw "beef" samples containing horse and deer meat (Ayaz et al., 364 2006). The results of these studies combined with the current study indicate that meat species 365 substitution and adulteration occurs in processed foods intended for either human or animal 366 consumption. Some potential factors contributing to this mislabeling trend may be (1) intentional 367 substitution with cheaper alternative meat species for economic gain or (2) unintentional 368 substitution caused by accidental cross-contamination in the production chain.

369 While a seemingly high percentage of pet foods were found to be potentially mislabeled 370 in this study, the manner in which mislabeling occurred is not clear. For example, it is unknown 371 as to whether the mislabeling was intentional or accidental and at which point(s) in the 372 production chain it took place. Real-time PCR is a sensitive assay that is capable of picking up 373 on low levels of DNA in a product. For example, the real-time PCR assay developed by Yancy et 374 al. (2009) was reported to be capable of identifying species in animal feeds at levels as low as $3750.1 \%$. In manufacturing and processing plants that handle more than one meat species on the 376 same equipment, some animal tissue may remain and contaminate the next product during 377 processing and handling, especially in instances where the equipment is not thoroughly cleaned 378 and sanitized between product lines (Premanandh, 2013). Another possible reason for the 379 mislabeling observed is due to a lack of traceability from the farm to the final food product 
380 (Shackell, 2008), which may allow for intentional or unintentional substitution of one animal

381 product for another to go unnoticed or undocumented.

382

\section{Acknowledgements}

395 The authors gratefully thank Chapman University Schmid College of Science and Technology

396 for their support and Taylor Patti for assisting with real-time PCR laboratory work.

\section{$397 \quad$ References}

AAFCO. (2013). Association of American Feed Control Officials. 2013 Official Publication. APPA. (2013). American Pet Products Association. U.S. Pet Industry Market Size \& Ownership Statistics.

Ayaz, Y., Ayaz, N. D., \& Erol, I. (2006). Detection of species in meat and meat products using enzyme-linked immunosorbent assay. Journal of Muscle Foods, 17(2), 214-220. 
Ballin, N. Z., Vogensen, F. K., \& Karlsson, A. H. (2009). Species determination - Can we detect and quantify meat adulteration? Meat Science, 83(2), 165-174.

Cawthorn, D. M., Steinman, H. A., \& Hoffman, L. C. (2013). A high incidence of species substitution and mislabelling detected in meat products sold in South Africa. Food Control, 32(2), 440-449.

FDA. (2010). Food and Drug Administration. Animal and Veterinary Section: Pet Food Labels General. Accessible at: http://www.fda.gov/AnimalVeterinary/ResourcesforYou/ucm047113.htm. Accessed $3 / 24 / 2014$.

Flores-Munguia, M. E., Bermudez-Almada, M. C., \& Vazquez-Moreno, L. (2000). A research note: Detection of adulteration in processed traditional meat products. Journal of Muscle Foods, 11(4), 319-325.

Hellberg, R. S., Kawalek, M. D., Van, K. T., Shen, Y., \& Williams-Hill, D. M. (2014). Comparison of DNA extraction and PCR setup methods for use in high-throughput DNA barcoding of fish species. Food Analytical Methods. Advance online publication. doi:10.1007/s12161-014-9865-z

Henderson, S. (2013). Spending on pets: "Tails" from the Consumer Expenditure Survey. Beyond the Numbers: Prices \& Spending, 2(16).

Hsieh, Y. H. P., Woodward, B. B., \& Ho, S. H. (1995). Detection of species substitution in raw and cooked meats using immunoassays. Journal of Food Protection, 58(5), 555-559.

Kesmen, Z., Sahin, F., \& Yetim, H. (2007). PCR assay for the identification of animal species in cooked sausages. Meat Science, 77, 649-653. 
425 Marti, D. L., Johnson, R. J., \& Mathews, K. H., Jr. (2011). Where's the (not) meat? Byproducts from beef and pork production. In: USDA Economic Research Service.

427 Montowska, M., \& Pospiech, E. (2011). Authenticity determination of meat and meat products

$428 \quad$ on the protein and DNA basis. Food Reviews International, 27(1), 84-100.

429 Moore, J. C., Spink, J., \& Lipp, M. (2012). Development and application of a database of food ingredient fraud and economically motivated adulteration from 1980 to 2010. Journal of Food Science, 77(4), R118-R126.

432 Mundi, I. (2014). Lamb monthly price - U.S. cents per pound. Accessible at: http://www.indexmundi.com/commodities/?commodity=lamb\&months=300. Accessed $3 / 24 / 2014$. prices-for-chicken-beef-and-pork/. Accessed 3/24/2014. International Journal of Medicine, 106(6), 595-597.

441 Ozpinar, H., Tezmen, G., Gokce, I., \& Tekiner, I. H. (2013). Detection of Animal Species in Some Meat and Meat Products by Comparatively Using DNA Microarray and Real Time

444 Premanandh, J. (2013). Horse meat scandal - A wake-up call for regulatory authorities. Food Control, 34(2), 568-569. 
Raditic, D. M., Remillard, R. L., \& Tater, K. C. (2011). ELISA testing for common food antigens in four dry dog foods used in dietary elimination trials. Journal of Animal Physiology and Animal Nutrition, 95(1), 90-97.

Ricci, R., Granato, A., Vascellari, M., Boscarato, M., Palagiano, C., Andrighetto, I., Diez, M., \& Mutinelli, F. (2013). Identification of undeclared sources of animal origin in canine dry foods used in dietary elimination trials. Journal of Animal Physiology and Animal Nutrition, 97, 32-38.

Schroeder, T. C., \& Tonsor, G. T. (2012). International cattle ID and traceability: Competitive implications for the US. Food Policy, 37, 31-40.

Shackell, G. H. (2008). Traceability in the meat industry - the farm to plate continuum. International Journal of Food Science and Technology, 43(12), 2134-2142.

Spink, J., \& Moyer, D. C. (2011). Defining the public health threat of food fraud. Journal of Food Science, 76(9), R157.

Spink, J., \& Moyer, D. C. (2013). Understanding and combating food fraud. Food Technology(1), 30 .

Stanciu, S., Stanciuc, N., Dumitrascu, L., Ion, R., \& Nistor, C. (2013). The effects of horse meat scandal on Romanian meat market. Cross-Cultural Management Journal, 27(1), 174.

USDA. (2005). United States Department of Agriculture. Identification of Animal Species in Meat and Poultry Products. Food Safety Inspection Service, Office of Public Health Science, MLG 17.02.

USDA. (2013). United States Department of Agriculture. Animal Disease Traceability: General Standards, v2.2. Accessible at: 
470 Verlinden, A., Hesta, M., Millet, S., \& Janssens, G. P. J. (2006). Food allergy in dogs and cats: A review. Critical Reviews in Food Science and Nutrition, 46(3), 259-273.

472 Vogelnest, L. J., \& Cheng, K. Y. (2013). Cutaneous adverse food reactions in cats: retrospective evaluation of 17 cases in a dermatology referral population (2001-2011). Australian Veterinary Journal, 91(11), 443-451.

475 Yancy, H. F., Washington, J. D., Callahan, L., Mason, J. A., Deaver, C. M., Farrell, D. E., Ha, T. A. I., Sespico, E., Falmlen, D., \& Myers, M. J. (2009). Development, evaluation, and peer verification of a rapid real-time PCR method for the detection of animal material. Journal of Food Protection, 72(11), 2368-2374.

\section{Figure Captions.}

483 Figure 1. Number of products $(n=52)$ containing the tested meat species. 
Table 1. Results of meat species identification in pet food products and treats by real-time PCR.

\begin{tabular}{|c|c|c|c|c|c|c|c|c|c|c|}
\hline \multirow[b]{2}{*}{$\begin{array}{l}\text { Sample } \\
\text { No. } \\
\end{array}$} & \multirow[b]{2}{*}{$\begin{array}{l}\text { Product } \\
\text { Type }\end{array}$} & \multirow[b]{2}{*}{ Meat Ingredients } & \multicolumn{8}{|c|}{ Meat Species } \\
\hline & & & $\begin{array}{c}\text { Bovine } \\
\text { (beef) }\end{array}$ & $\begin{array}{c}\text { Caprine } \\
\text { (goat) }\end{array}$ & $\begin{array}{r}\text { Ovine } \\
\text { (lamb) }\end{array}$ & $\begin{array}{c}\text { Chicken } \\
\text { (avian) }\end{array}$ & $\begin{array}{c}\text { Goose } \\
\text { (avian) }\end{array}$ & $\begin{array}{l}\text { Turkey } \\
\text { (avian) }\end{array}$ & $\begin{array}{c}\text { Porcine } \\
\text { (pork) }\end{array}$ & $\begin{array}{l}\text { Equine } \\
\text { (horse) }\end{array}$ \\
\hline P001 & $\begin{array}{l}\text { Dog food } \\
\text { (wet) }\end{array}$ & $\begin{array}{l}\text { Beef by-products } \\
\text { Liver (beef) } \\
\text { Meat by-products } \\
\text { Chicken } \\
\text { Chicken by-products }\end{array}$ & + & - & - & + & - & - & - & - \\
\hline $\mathrm{P} 002^{\mathrm{a}}$ & $\begin{array}{l}\text { Dog food } \\
\text { (wet) }\end{array}$ & $\begin{array}{l}\text { Deboned beef } \\
\text { Beef broth }\end{array}$ & $-{ }^{b}$ & - & - & - & - & - & $+^{c}$ & - \\
\hline $\mathrm{P} 003^{\mathrm{a}}$ & $\begin{array}{l}\text { Dog food } \\
\text { (wet) }\end{array}$ & $\begin{array}{l}\text { Chicken broth } \\
\text { Chicken } \\
\text { Turkey } \\
\text { Beef } \\
\text { Chicken liver } \\
\text { Beef liver } \\
\text { Lamb }\end{array}$ & + & - & + & + & - & $-{ }^{b}$ & - & - \\
\hline $\mathrm{P} 004^{\mathrm{a}}$ & $\begin{array}{l}\text { Dog food } \\
\text { (wet) }\end{array}$ & $\begin{array}{l}\text { Beef } \\
\text { Liver (beef) } \\
\text { Meat by-products } \\
\text { Turkey }\end{array}$ & $-{ }^{b}$ & - & - & - & - & + & + & - \\
\hline $\mathrm{P} 005^{\mathrm{a}}$ & $\begin{array}{l}\text { Dog food } \\
\text { (wet) }\end{array}$ & $\begin{array}{l}\text { Liver (lamb) } \\
\text { Lamb } \\
\text { Meat by-products } \\
\text { Turkey }\end{array}$ & - & - & + & $+^{c}$ & - & + & + & - \\
\hline $\mathrm{P}_{006}{ }^{\mathrm{a}}$ & $\begin{array}{l}\text { Dog food } \\
\text { (wet) }\end{array}$ & $\begin{array}{l}\text { Pork } \\
\text { Liver (pork) } \\
\text { Chicken } \\
\text { Meat by-products }\end{array}$ & + & - & - & + & - & $+^{\mathrm{c}}$ & + & - \\
\hline P007 & $\begin{array}{l}\text { Dog food } \\
\text { (wet) }\end{array}$ & $\begin{array}{l}\text { Meat broth } \\
\text { Beef } \\
\text { Pork liver } \\
\text { Ham (pork) } \\
\text { Animal plasma }\end{array}$ & + & - & - & + & - & + & + & - \\
\hline P008 & $\begin{array}{l}\text { Dog food } \\
\text { (wet) }\end{array}$ & $\begin{array}{l}\text { Turkey } \\
\text { Pork liver } \\
\text { Pork plasma } \\
\text { Chicken fat } \\
\end{array}$ & $+^{c}$ & - & - & + & - & + & + & - \\
\hline P009 & $\begin{array}{l}\text { Cat food } \\
\text { (wet) }\end{array}$ & $\begin{array}{l}\text { Poultry broth } \\
\text { Turkey } \\
\text { Liver (turkey) } \\
\text { Meat by-products } \\
\text { Chicken }\end{array}$ & + & - & - & + & - & + & - & - \\
\hline
\end{tabular}




\begin{tabular}{|c|c|c|c|c|c|c|c|c|c|c|}
\hline \multirow[b]{2}{*}{$\begin{array}{l}\text { Sample } \\
\text { No. }\end{array}$} & \multirow[b]{2}{*}{$\begin{array}{l}\text { Product } \\
\text { Type }\end{array}$} & \multirow[b]{2}{*}{ Meat Ingredients } & \multicolumn{8}{|c|}{ Meat Species } \\
\hline & & & $\begin{array}{c}\text { Bovine } \\
\text { (beef) }\end{array}$ & $\begin{array}{c}\text { Caprine } \\
\text { (goat) }\end{array}$ & $\begin{array}{c}\text { Ovine } \\
\text { (lamb) }\end{array}$ & $\begin{array}{c}\text { Chicken } \\
\text { (avian) }\end{array}$ & $\begin{array}{c}\text { Goose } \\
\text { (avian) }\end{array}$ & $\begin{array}{l}\text { Turkey } \\
\text { (avian) }\end{array}$ & $\begin{array}{c}\begin{array}{c}\text { Porcine } \\
\text { (pork) }\end{array} \\
\end{array}$ & $\begin{array}{l}\text { Equine } \\
\text { (horse) }\end{array}$ \\
\hline $\mathrm{P} 010^{\mathrm{a}}$ & $\begin{array}{l}\text { Cat food } \\
\text { (wet) }\end{array}$ & $\begin{array}{l}\text { Meat broth } \\
\text { Chicken } \\
\text { Meat by-products } \\
\text { Chicken by-products } \\
\text { Lamb }\end{array}$ & - & - & + & + & - & $+{ }^{c}$ & - & - \\
\hline $\mathrm{P} 011^{\mathrm{d}}$ & $\begin{array}{l}\text { Cat food } \\
\text { (wet) }\end{array}$ & $\begin{array}{l}\text { Meat by-products } \\
\text { Chicken } \\
\text { Poultry by-products }\end{array}$ & - & - & - & + & - & + & - & - \\
\hline P012 & $\begin{array}{l}\text { Cat food } \\
\text { (wet) }\end{array}$ & $\begin{array}{l}\text { Chicken } \\
\text { Chicken broth } \\
\text { Beef } \\
\text { Chicken fat }\end{array}$ & + & - & - & + & - & - & - & - \\
\hline $\mathrm{P} 013^{\mathrm{a}}$ & $\begin{array}{l}\text { Cat food } \\
\text { (wet) }\end{array}$ & $\begin{array}{l}\text { Pork } \\
\text { Pork broth } \\
\text { Pork liver } \\
\end{array}$ & $+c$ & - & - & $+\mathrm{c}$ & - & - & + & - \\
\hline $\mathrm{P} 014^{\mathrm{a}}$ & $\begin{array}{l}\text { Cat food } \\
\text { (wet) }\end{array}$ & $\begin{array}{l}\text { Chicken } \\
\text { Chicken liver } \\
\text { Pork by-products }\end{array}$ & $+c$ & - & - & + & - & - & + & - \\
\hline $\mathrm{P} 015^{\mathrm{a}}$ & $\begin{array}{l}\text { Cat food } \\
\text { (wet) }\end{array}$ & $\begin{array}{l}\text { Chicken } \\
\text { Turkey giblets } \\
\text { Meat by-products } \\
\text { Liver (chicken) } \\
\text { Chicken fat }\end{array}$ & + & - & - & + & - & $-{ }^{b}$ & - & - \\
\hline $\mathrm{P} 016^{\mathrm{a}}$ & $\begin{array}{l}\text { Cat food } \\
\text { (wet) }\end{array}$ & $\begin{array}{l}\text { Beef } \\
\text { Beef broth } \\
\text { Beef liver } \\
\text { Lamb liver } \\
\text { Venison } \\
\text { Lamb } \\
\text { Chicken meal }\end{array}$ & $-{ }^{b}$ & - & $-{ }^{b}$ & + & - & $+^{c}$ & $+^{c}$ & - \\
\hline $\mathrm{P} 017^{\mathrm{a}}$ & $\begin{array}{l}\text { Cat food } \\
\text { (wet) }\end{array}$ & $\begin{array}{l}\text { Liver (turkey) } \\
\text { Turkey } \\
\text { Meat by-products } \\
\text { Chicken }\end{array}$ & - & + & - & + & - & $-{ }^{b}$ & - & - \\
\hline P018 & $\begin{array}{l}\text { Dog food } \\
\text { (dry) }\end{array}$ & $\begin{array}{l}\text { Meat \& bone meal } \\
\text { Animal fat }\end{array}$ & + & - & + & + & - & + & - & - \\
\hline P019a & $\begin{array}{l}\text { Dog food } \\
\text { (dry) }\end{array}$ & $\begin{array}{l}\text { Chicken } \\
\text { Chicken meal } \\
\text { Beef fat }\end{array}$ & + & - & $+c$ & + & - & $+^{c}$ & $+c$ & - \\
\hline
\end{tabular}




\begin{tabular}{|c|c|c|c|c|c|c|c|c|c|c|}
\hline \multirow[b]{2}{*}{$\begin{array}{l}\text { Sample } \\
\text { No. }\end{array}$} & \multirow[b]{2}{*}{$\begin{array}{l}\text { Product } \\
\text { Type }\end{array}$} & \multirow[b]{2}{*}{ Meat Ingredients } & \multicolumn{8}{|c|}{ Meat Species } \\
\hline & & & $\begin{array}{c}\text { Bovine } \\
\text { (beef) }\end{array}$ & $\begin{array}{c}\text { Caprine } \\
\text { (goat) }\end{array}$ & $\begin{array}{c}\text { Ovine } \\
\text { (lamb) }\end{array}$ & $\begin{array}{c}\text { Chicken } \\
\text { (avian) }\end{array}$ & $\begin{array}{c}\text { Goose } \\
\text { (avian) }\end{array}$ & $\begin{array}{l}\text { Turkey } \\
\text { (avian) }\end{array}$ & $\begin{array}{c}\begin{array}{c}\text { Porcine } \\
\text { (pork) }\end{array} \\
\end{array}$ & $\begin{array}{l}\text { Equine } \\
\text { (horse) }\end{array}$ \\
\hline P020 & $\begin{array}{l}\text { Dog food } \\
\text { (dry) }\end{array}$ & $\begin{array}{l}\text { Chicken by-product meal } \\
\text { Beef tallow } \\
\text { Beef } \\
\text { Animal fat }\end{array}$ & + & + & + & + & - & + & + & - \\
\hline P021 & $\begin{array}{l}\text { Dog food } \\
\text { (dry) }\end{array}$ & $\begin{array}{l}\text { Beef \& bone meal } \\
\text { Animal fat } \\
\text { Animal digest }\end{array}$ & + & - & - & + & - & - & + & - \\
\hline P022 & $\begin{array}{l}\text { Dog food } \\
\text { (dry) }\end{array}$ & $\begin{array}{l}\text { Chicken by-product meal } \\
\text { Animal fat } \\
\text { Beef } \\
\text { Meat \& bone meal } \\
\text { Animal digest }\end{array}$ & + & - & + & + & - & + & + & - \\
\hline $\mathrm{P} 023^{\mathrm{a}}$ & $\begin{array}{l}\text { Dog food } \\
\text { (dry) }\end{array}$ & $\begin{array}{l}\text { Lamb meal } \\
\text { Poultry fat }\end{array}$ & $+{ }^{c}$ & - & + & + & - & + & $+{ }^{c}$ & - \\
\hline P024 & $\begin{array}{l}\text { Dog food } \\
\text { (dry) }\end{array}$ & $\begin{array}{l}\text { Meat \& bone meal } \\
\text { Animal fat }\end{array}$ & + & + & + & + & - & + & + & - \\
\hline P025 & $\begin{array}{l}\text { Dog food } \\
\text { (dry) }\end{array}$ & $\begin{array}{l}\text { Chicken by-product meal } \\
\text { Animal fat } \\
\text { Chicken }\end{array}$ & - & - & + & + & - & + & - & - \\
\hline P026 & $\begin{array}{l}\text { Dog food } \\
\text { (dry) }\end{array}$ & $\begin{array}{l}\text { Beef } \\
\text { Animal fat } \\
\text { Poultry by-product meal } \\
\text { Animal digest }\end{array}$ & + & - & + & + & - & + & + & - \\
\hline P027 & $\begin{array}{l}\text { Cat food } \\
\text { (dry) }\end{array}$ & $\begin{array}{l}\text { Chicken } \\
\text { Chicken meal } \\
\text { Animal fat }\end{array}$ & + & - & + & + & - & + & + & - \\
\hline P028 & $\begin{array}{l}\text { Cat food } \\
\text { (dry) }\end{array}$ & $\begin{array}{l}\text { Chicken } \\
\text { Chicken by-product meal } \\
\text { Chicken meal } \\
\text { Animal fat }\end{array}$ & - & + & + & + & - & + & + & - \\
\hline P029 & $\begin{array}{l}\text { Cat food } \\
\text { (dry) }\end{array}$ & $\begin{array}{l}\text { Chicken meal } \\
\text { Animal fat } \\
\text { Chicken }\end{array}$ & + & - & + & + & - & + & + & - \\
\hline P030 & $\begin{array}{l}\text { Cat food } \\
\text { (dry) }\end{array}$ & $\begin{array}{l}\text { Poultry by-product meal } \\
\text { Animal fat } \\
\text { Animal digest } \\
\text { Chicken meal } \\
\text { Turkey by-product meal }\end{array}$ & + & + & - & + & - & + & + & - \\
\hline
\end{tabular}




\begin{tabular}{|c|c|c|c|c|c|c|c|c|c|c|}
\hline \multirow[b]{2}{*}{$\begin{array}{l}\text { Sample } \\
\text { No. }\end{array}$} & \multirow[b]{2}{*}{$\begin{array}{l}\text { Product } \\
\text { Type }\end{array}$} & \multirow[b]{2}{*}{ Meat Ingredients } & \multicolumn{8}{|c|}{ Meat Species } \\
\hline & & & $\begin{array}{c}\text { Bovine } \\
\text { (beef) }\end{array}$ & $\begin{array}{c}\text { Caprine } \\
\text { (goat) }\end{array}$ & $\begin{array}{c}\text { Ovine } \\
\text { (lamb) }\end{array}$ & $\begin{array}{c}\text { Chicken } \\
\text { (avian) }\end{array}$ & $\begin{array}{c}\text { Goose } \\
\text { (avian) }\end{array}$ & $\begin{array}{l}\text { Turkey } \\
\text { (avian) }\end{array}$ & $\begin{array}{c}\text { Porcine } \\
\text { (pork) }\end{array}$ & $\begin{array}{l}\text { Equine } \\
\text { (horse) }\end{array}$ \\
\hline P031 & $\begin{array}{l}\text { Cat food } \\
\text { (dry) }\end{array}$ & $\begin{array}{l}\text { Chicken by-product meal } \\
\text { Beef tallow } \\
\text { Animal digest } \\
\text { Turkey by-product meal }\end{array}$ & + & - & + & + & - & + & - & - \\
\hline P032 & $\begin{array}{l}\text { Cat food } \\
\text { (dry) }\end{array}$ & $\begin{array}{l}\text { Poultry by-product meal } \\
\text { Animal fat } \\
\text { Chicken }\end{array}$ & + & - & + & + & - & - & + & - \\
\hline P033 & $\begin{array}{l}\text { Cat food } \\
\text { (dry) }\end{array}$ & $\begin{array}{l}\text { Chicken by-product meal } \\
\text { Meat \& bone meal } \\
\text { Beef tallow } \\
\text { Turkey by-product meal }\end{array}$ & + & - & + & + & - & + & + & - \\
\hline P034 & $\begin{array}{l}\text { Cat food } \\
\text { (dry) }\end{array}$ & $\begin{array}{l}\text { Poultry by-product meal } \\
\text { Animal fat }\end{array}$ & + & - & - & + & - & + & + & - \\
\hline $\mathrm{P} 035^{\mathrm{a}}$ & Dog treats & $\begin{array}{l}\text { Bacon } \\
\text { Bacon fat } \\
\text { Beef } \\
\end{array}$ & $-{ }^{\mathrm{b}}$ & - & - & $+\mathrm{c}$ & - & - & $-{ }^{b}$ & - \\
\hline P036 & Dog treats & Chicken & $+c$ & - & - & + & - & - & - & - \\
\hline $\mathrm{P} 037^{\mathrm{a}}$ & Dog treats & $\begin{array}{l}\text { Chicken } \\
\text { Beef }\end{array}$ & + & - & $+c$ & + & - & $+c$ & $+{ }^{c}$ & - \\
\hline P038 & Dog treats & $\begin{array}{l}\text { Lamb } \\
\text { Poultry fat }\end{array}$ & - & - & + & + & - & + & - & - \\
\hline P039a & Dog treats & $\begin{array}{l}\text { Meat \& bone meal } \\
\text { Beef fat }\end{array}$ & + & + & - & $+c$ & - & $+{ }^{c}$ & - & - \\
\hline P040 & Dog treats & $\begin{array}{l}\text { Chicken by-product meal } \\
\text { Beef } \\
\text { Animal fat }\end{array}$ & + & - & + & + & - & - & - & - \\
\hline $\mathrm{P} 041^{\mathrm{a}}$ & Dog treats & $\begin{array}{l}\text { Beef } \\
\text { Beef by-products } \\
\text { Beef liver }\end{array}$ & + & - & - & $++^{c}$ & - & - & $+c$ & - \\
\hline P042 & Dog treats & $\begin{array}{l}\text { Beef } \\
\text { Liver } \\
\text { Animal fat } \\
\text { Chicken by-product meal }\end{array}$ & + & + & + & + & - & + & + & - \\
\hline P043 & Dog treats & $\begin{array}{l}\text { Bacon } \\
\text { Dried bacon fat } \\
\text { Animal fat } \\
\end{array}$ & + & + & + & + & - & - & + & - \\
\hline P044 & Dog treats & $\begin{array}{l}\text { Chicken } \\
\text { Animal fat }\end{array}$ & - & + & + & + & - & + & - & - \\
\hline $\mathrm{P} 045^{\mathrm{a}}$ & Cat treats & $\begin{array}{l}\text { Chicken } \\
\text { Chicken meal }\end{array}$ & - & - & - & + & - & - & $+{ }^{c}$ & - \\
\hline
\end{tabular}




\begin{tabular}{|c|c|c|c|c|c|c|c|c|c|c|}
\hline \multirow[b]{2}{*}{$\begin{array}{l}\text { Sample } \\
\text { No. }\end{array}$} & \multirow[b]{2}{*}{$\begin{array}{l}\text { Product } \\
\text { Type }\end{array}$} & \multirow[b]{2}{*}{ Meat Ingredients } & \multicolumn{8}{|c|}{ Meat Species } \\
\hline & & & $\begin{array}{c}\begin{array}{c}\text { Bovine } \\
\text { (beef) }\end{array} \\
\end{array}$ & $\begin{array}{c}\text { Caprine } \\
\text { (goat) }\end{array}$ & $\begin{array}{c}\text { Ovine } \\
\text { (lamb) }\end{array}$ & $\begin{array}{c}\text { Chicken } \\
\text { (avian) }\end{array}$ & $\begin{array}{c}\text { Goose } \\
\text { (avian) }\end{array}$ & $\begin{array}{l}\text { Turkey } \\
\text { (avian) }\end{array}$ & $\begin{array}{c}\begin{array}{c}\text { Porcine } \\
\text { (pork) }\end{array} \\
\end{array}$ & $\begin{array}{l}\text { Equine } \\
\text { (horse) }\end{array}$ \\
\hline P046 & Cat treats & Chicken & - & - & - & + & - & - & - & - \\
\hline P047 & Cat treats & $\begin{array}{l}\text { Chicken meal } \\
\text { Animal fat } \\
\text { Chicken }\end{array}$ & - & - & - & + & - & - & + & - \\
\hline P048 & Cat treats & $\begin{array}{l}\text { Chicken meal } \\
\text { Animal fat }\end{array}$ & - & - & - & + & - & - & + & - \\
\hline P049 & Cat treats & $\begin{array}{l}\text { Chicken meal } \\
\text { Animal fat } \\
\text { Bacon } \\
\end{array}$ & + & - & + & + & - & + & + & - \\
\hline P050 & Cat treats & $\begin{array}{l}\text { Animal liver } \\
\text { Chicken by-product meal } \\
\text { Animal fat }\end{array}$ & - & - & - & + & - & - & + & - \\
\hline P051 & Cat treats & $\begin{array}{l}\text { Chicken meal } \\
\text { Animal fat } \\
\text { Dried meat by-products }\end{array}$ & - & - & + & + & - & - & + & - \\
\hline P052 & Cat treats & $\begin{array}{l}\text { Chicken by-product meal } \\
\text { Animal fat } \\
\text { Dried meat-by products }\end{array}$ & - & - & + & + & + & + & + & - \\
\hline
\end{tabular}

486 a Potentially mislabeled.

$487 \quad{ }^{\mathrm{b}}$ Meat species listed on the product label was not detected.

$488{ }^{\mathrm{c}}$ Contains undeclared meat species.

489 d Labeling could not be confirmed. 
Table 2. Meat species detected in products $(n=38)$ with non-specific meat ingredients on the label.

\begin{tabular}{|c|c|c|c|c|c|c|c|c|}
\hline \multirow[b]{2}{*}{$\begin{array}{l}\text { Non-specific meat } \\
\text { ingredients on label }\end{array}$} & \multicolumn{8}{|c|}{ Number of products containing each meat species } \\
\hline & $\begin{array}{c}\text { Bovine } \\
\text { (beef) }\end{array}$ & $\begin{array}{c}\text { Caprine } \\
\text { (goat) }\end{array}$ & $\begin{array}{c}\text { Ovine } \\
\text { (lamb) }\end{array}$ & Chicken & Goose & Turkey & $\begin{array}{c}\text { Porcine } \\
\text { (pork) }\end{array}$ & $\begin{array}{l}\text { Equine } \\
\text { (horse) }\end{array}$ \\
\hline $\begin{array}{l}\text { "Animal fat" or "Poultry fat" } \\
(n=25)\end{array}$ & 16 & 7 & 19 & 25 & 1 & 17 & 20 & 0 \\
\hline $\begin{array}{l}\text { "Meat by-product" or "Dried } \\
\text { meat by-product" } \\
(n=11)\end{array}$ & 4 & 1 & 4 & - & - & - & 5 & 0 \\
\hline "Meat \& bone meal" $(n=5)$ & 5 & 2 & 4 & - & - & - & 3 & 0 \\
\hline “Animal digest" $(n=5)$ & 5 & 1 & 3 & 5 & 0 & 4 & 4 & 0 \\
\hline $\begin{array}{l}\text { "Poultry by-product meal" } \\
(n=4)\end{array}$ & - & - & - & 4 & 0 & 4 & - & - \\
\hline
\end{tabular}




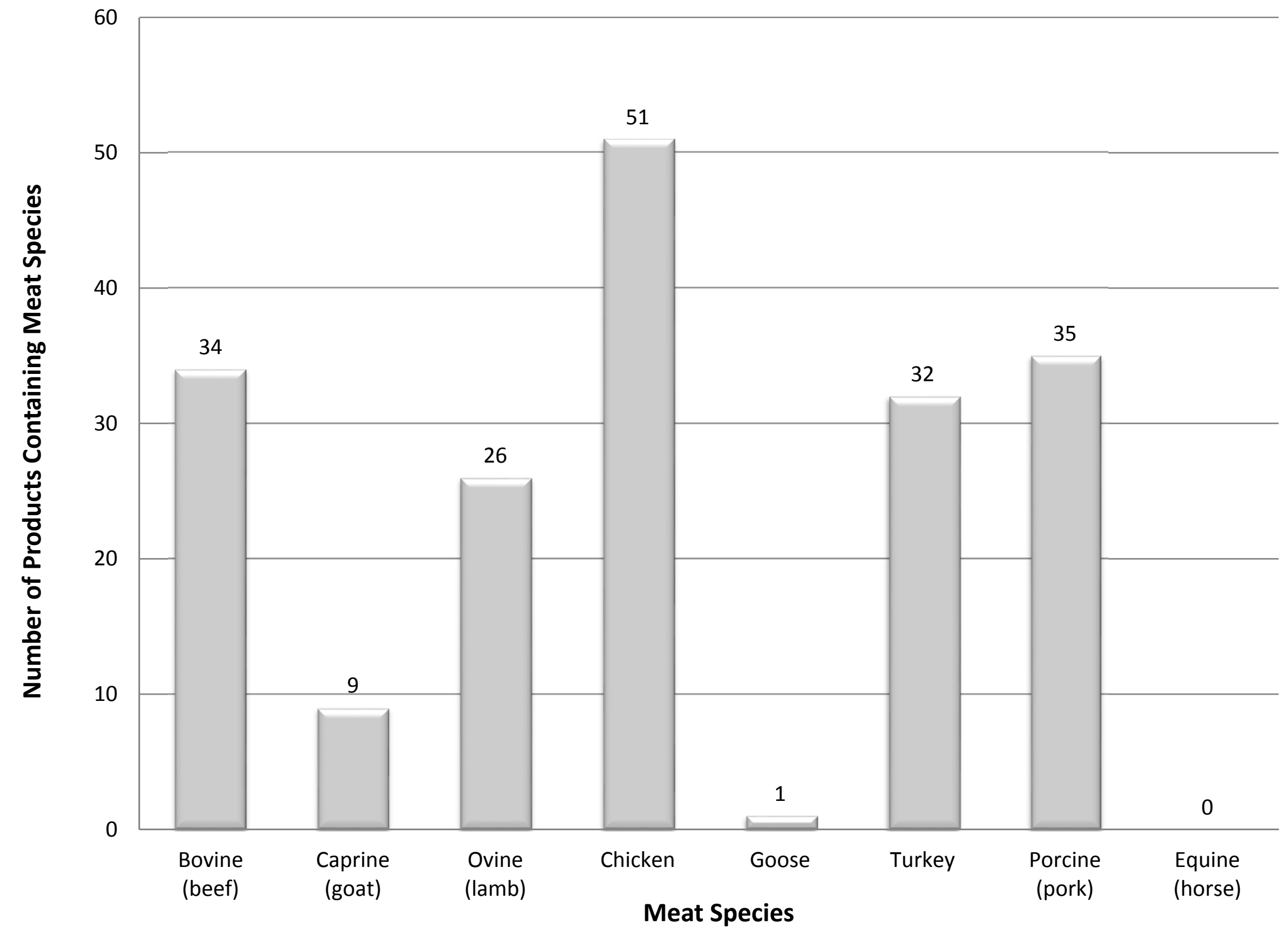

